\title{
A simple method to remove a tight ring using two nylon strings attached to a curved needle
}

\author{
W V V de Silva ${ }^{1}$, S Sritharan ${ }^{2}$ \\ Ceylon Medical Journal 2018; 63: 82-83 \\ DOI: http://doi.org/10.4038/cmj.v63i2.8681
}

\section{Introduction}

Although rings are considered safe jewellery, they may become unduly tight in the presence of infections, skin disorders, allergic reactions, pregnancy and fractures of the limb. Removal of a tight ring is challenging. If not attended to urgently it can lead to neurovascular compromise of distal tissues [1].

There are different techniques of removing a tight ring. One is to wrap a self-adhesive tape around the distal oedematous area [1]. A suture wound tightly around the swollen area may allow the ring to slip over it [1]. A tight fitting surgical glove placed over the affected area can be slipped under the tight ring [1]. Finally the ring can be cut using appropriate equipment [3]. These methods are cumbersome to the patient and may not be successful. Cutting the ring requires special equipment and the jewellery will lose its value.
We describe a simple and easy technique to remove a tight ring using two nylon sutures attached to eyeless number 2 round bodied needles.

\section{Technique and cases}

Informed written consent was obtained from the patients before the procedure. Initial lubrication using $4 \%$ chlorhexidine gluconate was applied and then the blunt end of a curved round bodied needle (number 2 size) with a nylon suture attached was passed under the ring and two separate loops were formed (Figure 1). Artery forceps were used to hold the two ends of the strings securely in each hand (Figure 2). Nylon threads were pulled along the axis of the finger alternatively while rotating them (Figure 3). Procedure was continued until the ring was completely removed from the finger.

Table 1. Summary of the case details

\begin{tabular}{|c|c|c|}
\hline & Case description & Outcome \\
\hline Case 01 & $\begin{array}{l}45 \text { year old man presenting with a tight } \\
\text { ring on his right hand }\end{array}$ & $\begin{array}{l}\text { Initially } 2 \mathrm{ml} \text { of } 2 \% \text { lignocaine was infiltrated proximal } \\
\text { to the distal digital crease as a digital block. After } 5 \\
\text { minutes the ring was removed using above method. }\end{array}$ \\
\hline Case 02 & $\begin{array}{l}73 \text { year old woman with a left sided Colles } \\
\text { fracture and a tight ring on her ring finger }\end{array}$ & $\begin{array}{l}\text { Following a wrist block, a digital nerve block and } \\
\text { lubrication, the tight ring was removed. }\end{array}$ \\
\hline Case 03 & $\begin{array}{l}25 \text { year old motorist with a closed fracture } \\
\text { of the left forearm }\end{array}$ & $\begin{array}{l}\text { Following general anaesthesia the tight ring was } \\
\text { removed. }\end{array}$ \\
\hline
\end{tabular}

${ }^{1}$ Senior House Officer, National Hospital,Sri Lanka, ${ }^{2}$ Senior Consultant Orthopaedic Surgeon.

Correspondence: WVVDS, e-mail: <virajdesilva.vds@gmail.com>. Received 03 May 2018 and revised version accepted 18 May 2018.

This is an open-access article distributed under the terms of the Creative Commons Attribution License, which permits unrestricted use, distribution, and reproduction in any medium, provided the original author and source are credited. 


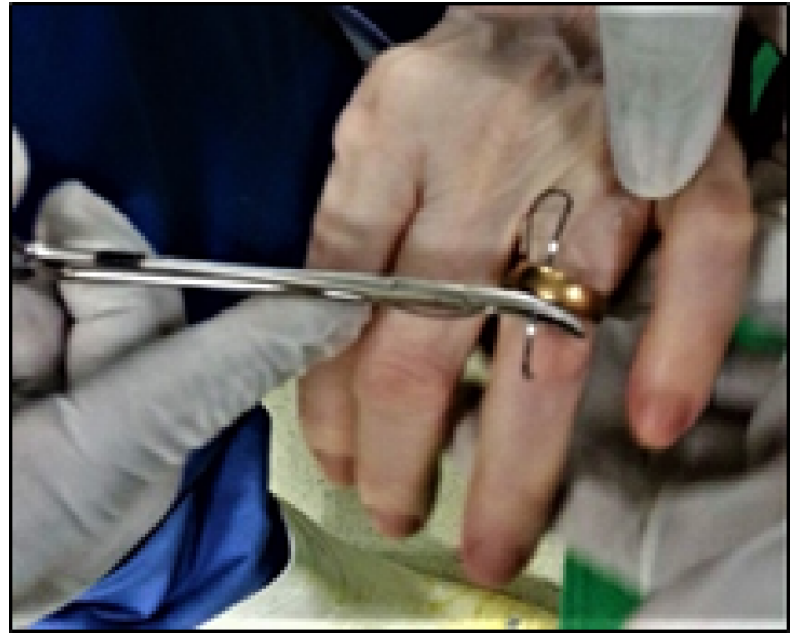

Figure 1. Following initial lubrication, blunt end of the curved needle with the nylon suture attached was passed under the ring.

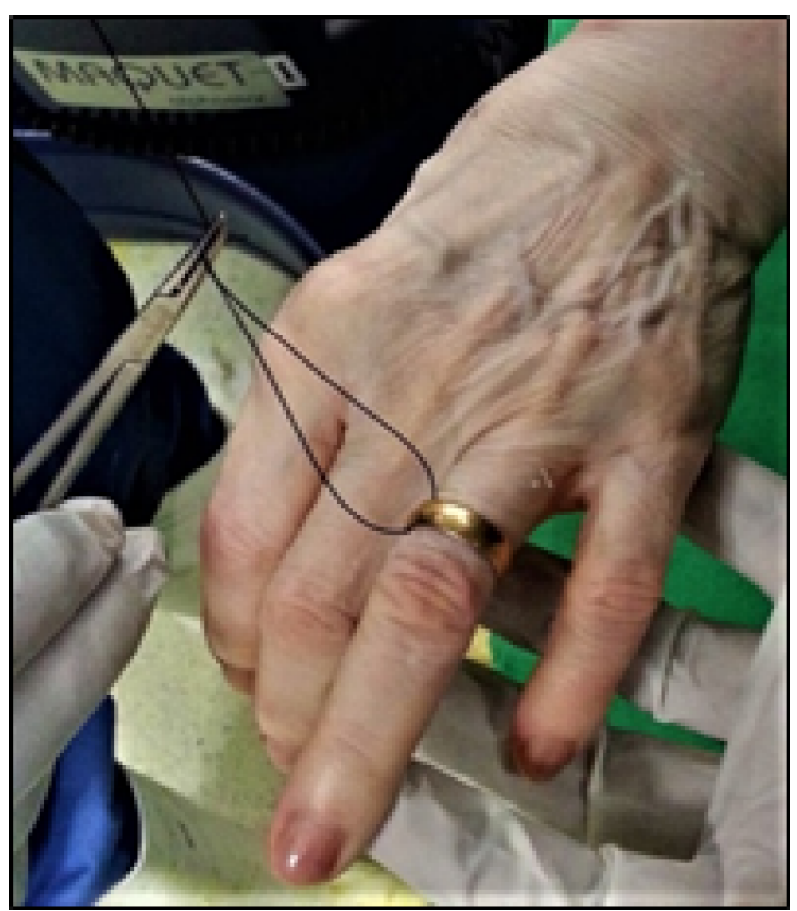

Figure 2. Artery forceps were used to hold the strings securely.

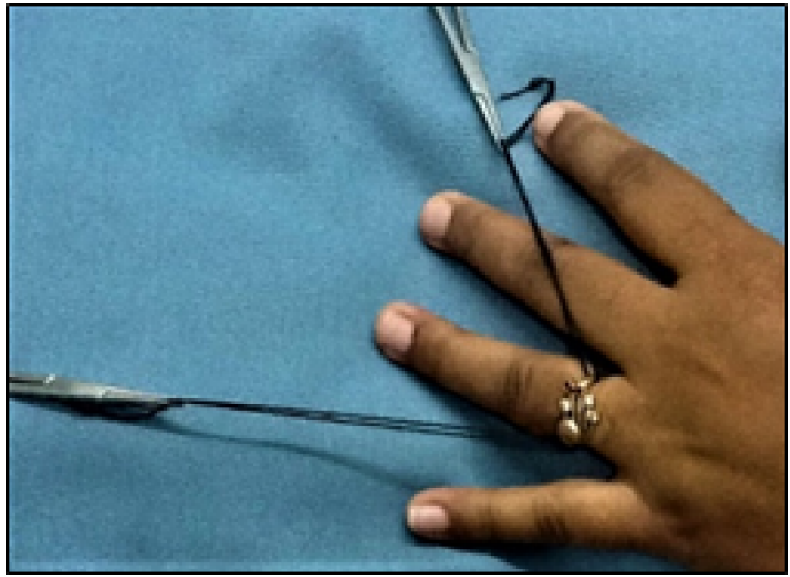

Figure 3. Nylon threads were pulled along the axis of the finger alternatively while rotating them.

\section{Discussion}

Although there are no established guidelines, Kalkan et al have proposed an algorithm to choose an appropriate method depending on the clincal presentation [1].

The ideal technique to remove a tight ring should be easy, safe and painless. Two widely practiced techniques are use of two rubber bands or strings [2]. Using only strings is challenging as passing it underneath the ring is not easy. However, the two nylon technique we described is easy and uses material readily available in emergency departments and can be performed in an outpatient setting. Furthermore, health care workers are familiar with using the paraphernalia necessary for the procedure.

\section{References}

1. Peckler B, Hsu CK. Tourniquet syndrome: A review of constricting band removal. J Emerg Med 2001; 20(3): 253-62.

2. Kalkan A, Kose O, Tas M, Meric G. Review of techniques for the removal of trapped rings on fingers with a proposed new algorithm. Am J Emerg Med 2013; 31(11): 1605-11.

3. Hajduk SV. Emergency removal of hard metal or ceramic finger rings. Ann Emerg Med 2001; 37(6): 736. 